DOI https://doi.org/10.18551/rjoas.2018-08.11

\title{
IMPACT OF ENTERPRISE RESOURCE PLANNING SYSTEMS ON THE ACCOUNTING INFORMATION RELEVANCE AND FIRM PERFORMANCE
}

\author{
Luciana Dwi May Adi Indra*, Soewarno Noorlailie, Isnalita \\ Faculty of Economic and Business, University of Airlangga, Indonesia \\ *E-mail: lucianamayadi@gmail.com
}

\begin{abstract}
ERP (Enterprise Resource Planning) system is considered to provide benefits for the company. ERP systems provide useful accounting information for decision making. This study aims to determine the impact of ERP systems on the relevance of accounting information and firm performance on companies that adopt ERP and companies that do not adopt ERP. In this study the relevance of accounting information is tested with three variables of predictive value, timeliness and feedback value. The results of this analysis are obtained from questionnaires that have been distributed to 75 companies, consisting of 40 companies that adopt ERP system and 35 companies that do not adoption of ERP system, the samples obtained by each of only 30 companies so that there are 60 companies studied. The hypothesis in this study will be tested using Mann Whitney nonparametric analysis with SPSS to look for differences in the impact of the two types of firms. This analysis proves that the ERP system affects the relevance of accounting information consisting of three variables and firm performance on companies that adopt ERP systems.
\end{abstract}

\section{KEY WORDS}

Enterprise resource planning, value relevance, firm, performance.

Technology has experienced a very fast development, everything will be easier with the help of technology. ERP system is one of the many technologies that facilitate decisionmaking and help the company's performance. This system helps companies in managing internal and external information into quality accounting information for decision making. Implementation of ERP within a company requires considerable configuration, but without reprogramming and the technology used should be in accordance with the requirements (Locke and Lowe, 2007).

The quality of information is a very important part for companies that are useful for decision making. The development of technology has created a competitive market competition so that companies compete to find ways to be able to process information quickly and effectively. HassabElnaby et al. in Attayah and Ibrahim (2014) state that competitive global business seeks to survive in competition by using information systems. The use of ERP systems is very useful for improving decision-making and companies keeps important information. Quality accounting information is influenced by strategies in obtaining information and information processing, this can improve the performance of the company (Ferdows and Meyer, 1990).

ERP system is not perfect, this system also fails but many companies do not care about that, they keep investing in ERP system (Ehie and Madsen, 2005). Companies adopt ERP systems hoping to get financial and non-financial benefits.

Galy and Mary (2014) argue that the ERP system requires the coordination of technology within the company, so that the implementation of the ERP system in the company will be successful and the company gets great benefits. Implementation of the ERP system in the company is quite helpful, so the financial statements are well controlled and will attract investors to invest in the company.

Implementation of ERP will initially require considerable cost, this is what makes some companies will think repeatedly in the implementation of ERP. But in the long run has a big enough profit than the cost incurred during implementation. Company spending will be trimmed with the implementation of the ERP system. 
Implementation of ERP is a broad process and costly enough, because ERP systems manage complex tasks. This system involves stakeholders such as managers, operational staff and knowledge that is widespread throughout implementation (Sevenpri, 2012).

Research conducted Behesthti and Behesthti (2010) ERP expenditures include the purchase of hardware and software, networking and consulting fees. The bigger the company, the cost needed for the implementation of ERP will be more and more. Implementation of ERP systems takes a long time, cost and trained resources so that ERP implementation poses a risk to the company (Hitt and Brynjolfsson, 1996).

This study examines the differences between companies that have adopted ERP and companies that do not adopt ERP in terms of value relevance include predictive value, timelines, feedback values and firm performance.

\section{LITERATURE REVIEW}

ERP is a software technology that helps organizations manage their business effectively and efficiently (Nah and Lau in Attayah and Ibrahim, 2014). This system helps the company's performance time and cost less. Implementation of early ERP requires training and long time, but the company will benefit so much.

Innovative technologies according to Drucker and Huber in Hunton, et al (2003) are technologies that can help organizational business processes, such as:

- Information that is more accurate, effective, efficient and provides complete external and internal information;

- Identify problems and opportunities accurately and effectively;

- The human resources needed are less to manage information;

- Organizations involved in decision-making are fewer;

- Decision making quickly, so the problem more quickly overcome.

ERP is a technological innovation to facilitate organizations in overcoming problems, because ERP is faster in decision making and has low cost because employees and organizations a bit. Research by Gatticker and Goodhue (2005) suggests that ERP systems have a significant impact if products used for production and distribution are optimized.

ERP is a useful system for integrating information systems that are useful for business infrastructure. Most systems can not measure company performance but ERP can provide performance measurement, this is very influential on decision making (Shen, et al., 2015).

Lorca and Andrés in Kocaoglu and Zafer (2015) stated that the ERP system is a standard system can overcome all the parameters needed in a structured manner. ERP is also a very innovative system and can complement other enterprise systems, ERP also has the ability to provide information on management. Dechow and Mouritsen (2005) identified in his research that the output of the ERP will vary according to the purpose of the user.

The relevance value is related to decision making in the opinion of Kieso (2011) that accounting information will be more useful for decision making, but they also have to consider the time and cost. Good decision-making must consider the past and be able to predict the future. In research conducted Attayah and Ibrahim (2014) argue that relevant accounting information is useful information for decision making.

The financial performance of firms adopting ERP according to Eliashberg and Chatterjee in Hunton, et al (2003) did not increase but differed from those that did not adopt ERP. The goal of ERP is to integrate technology, useful resources to meet customer demand and improve operational performance of the company. The benefits of ERP system adoption according to Chand et al. (2005) reduces operational costs and can increase corporate profits.

Wheatly in Alcivar (2016) describes problems that may affect the failure of ERP implementation, namely:

- Training employees about failed systems;

- Impact training for the company especially the cost issue;

- Hard negotiations between companies and ERP training vendors; 
- Implementation is done quickly so that the training takes place briefly;

- Employees have no knowledge of ERP system concept.

The success of the ERP system is influenced by the knowledge of the user through the process of understanding the system and the application of enterprise systems, so this will lead to system integration with management strategies so that system usage will be more optimal (Albers and Trinidad, 2006).

Research May et al. (2013) ERP systems have a significant impact on improving the products of manufacturing companies because ERP systems see how products are manufactured and optimized resources. Product improvement is influenced by three factors:

- The manager must ensure that the system used supports the development of the product;

- The manager must also ensure that the adopted system supports the growth of the product;

- The manager should ensure an opportunity to identify the product.

Environmental uncertainty makes managers difficulty making decisions, because the uncertain environment of information needed will tend to decrease. Reduced information due to coordination of activities (Madapusi and D'Souza, 2012).

Implementation of an optimal ERP system when its use is maximized, according to Scott and Vessey (2000) maximal system influenced by several factors as follows:

- Users should make sure that the ERP system is easy to use;

- Managers need to promote ERP system in the work environment;

- Users should also ensure that the ERP system is a flexible system;

- User ensures information can be used on time;

- Managers should ensure continuous use of ERP systems.

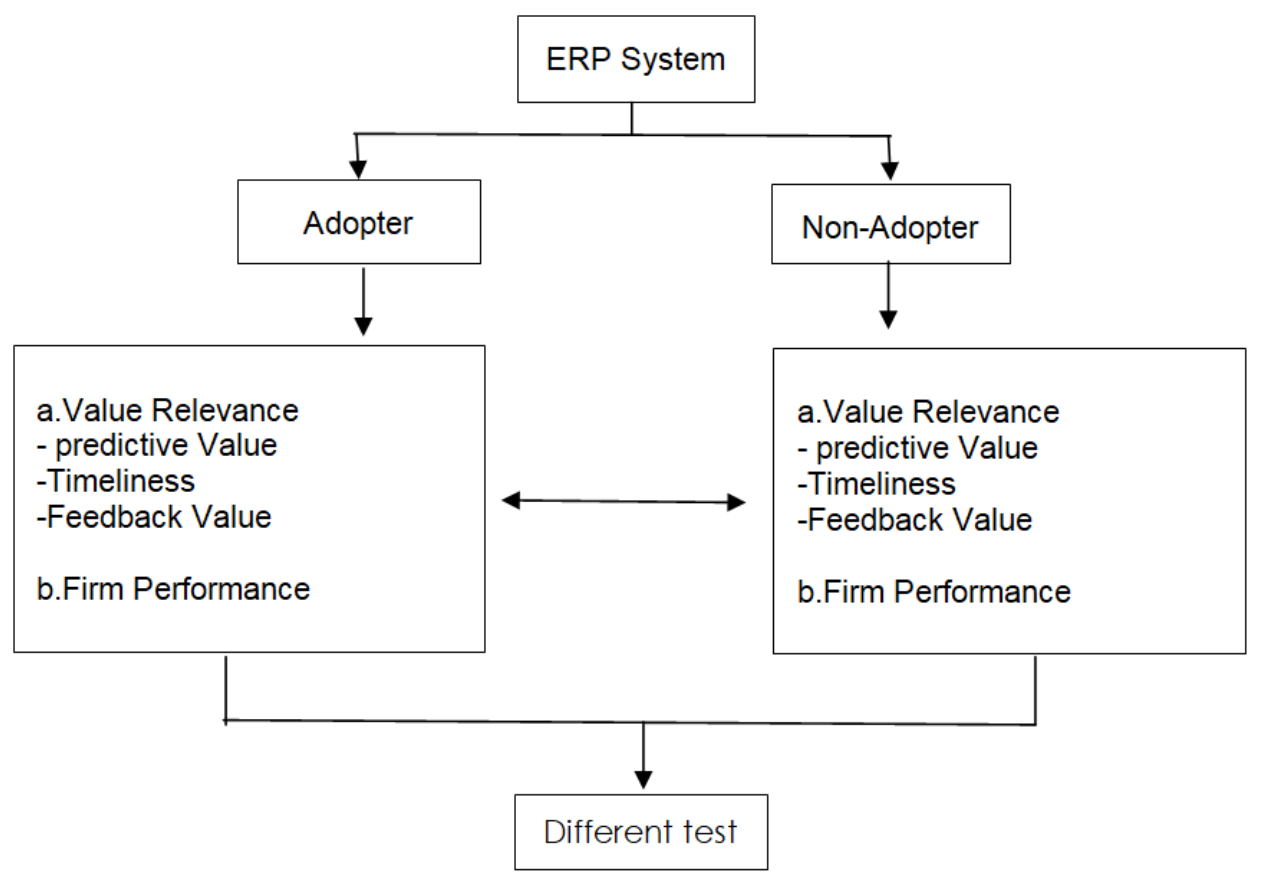

Figure 1 - Conceptual Framework

Hypothesis used in this research are:

$\mathrm{H} 1$ : There is a significant impact difference between adoption companies and nonadoption ERP companies in the relevance of accounting information due to the use of ERP systems.

The effect of ERP on the relevance of accounting information. The relevance of a company's accounting information is one of the benchmarks considered by potential investors and used for decision making, so the implementation of the ERP system impacts 
for the company. Attayah and Ibrahim's research (2014) states that the ERP system has a great influence on the relevance of corporate accounting information. The ERP system allows the company to have a better future because it can provide predictive value forecasting so managers can make rational decisions. Short processing of information so that data processing more and affect the relevance of accounting information.

$\mathrm{H} 2$ : There are significant differences in impact between adoption firms and nonadopted ERP companies in company performance due to the use of ERP systems.

Influence of ERP on company performance. Implementation of ERP system impact on company performance in accordance with research conducted by Hunton, et al. (2003), the company adopted an increase in company performance and this affects the profits derived by the company. This system helps the processing of information briefly so that employees will get plenty of time to improve creativity.

\section{METHODS OF RESEARCH}

This study uses a sample of 30 companies in each criteria of companies that adopt ERP and companies that do not adopt ERP. Data collection by sending questionnaires by email to each company. This study gives samples to companies with ERP adoption of 40 questionnaires and the questionnaire was answered as many as 30 companies. Distribution of questionnaires to companies that did not adopt ERP as many as 35 companies and answered as many as 30 questionnaires.

Hypotheses tested by questionnaire consisting of questions related to each variable that is predictive value variables as many as four questions, timeliness as many as six questions, feedback value as many as five questions and the last variable is the firm performance as many as 10 questions.

To test the hypothesis of this study divide the two samples of companies adopting ERP and companies that do not adopt ERP. Furthermore this study will examine the differences of ERP adoption firms and companies that did not adopt ERP by performing a nonparametric test of Mann Whitney on SPSS.

\section{RESULTS AND DISCUSSION}

The effect of the use of ERP systems on the relevance of accounting information and company performance, descriptive statistics consist of mean and standard deviation for adopting firms and non-adopting firms.

Table 1 - Descriptive Statistics

Descriptive statistics for all item

\begin{tabular}{clrrrr}
\hline \multirow{2}{*}{ No. } & \multirow{2}{*}{ Item } & \multicolumn{2}{c}{ Adopter } & \multicolumn{2}{c}{ Non Adopter } \\
\cline { 3 - 6 } & & Mean & SD & Mean & SD \\
\hline 1. & Predictive Item Average & 18.56 & 1.07 & 11.70 & 2.21 \\
\hline 2. & Timeliness Item Average & 25.56 & 2.37 & 18.53 & 4.26 \\
\hline 3. & Feedback Item Average & 19.70 & 2.23 & 16.07 & 1.89 \\
\hline 4. & Firm Performance Item Average & 40.36 & 0.71 & 31.67 & 5.25 \\
\hline & Total of all item & 26.04 & 1.60 & 19.50 & 3.40
\end{tabular}

Source : Data processed, 2017.

The table above shows the mean mean resulting from the company adoption of ERP is 26.04 while companies that do not adopt ERP is 19.50 . From these results indicate that the mean mean of firms that adopt ERP is greater than the mean mean of firms that do not adopt ERP. This proves that with the implementation of ERP system improves the ability to predict the past, predict the future, financial reporting can be done with a short time and improve company performance.

Implementation of ERP system influence to improvement of company performance supported by research conducted by Chou et al. (2017) using the ERP system, employees 
can shorten the time in work so as to share knowledge with other employees so that the knowledge of employees will increase and increase motivation to work.

Influence of ERP system to value of relevance of accounting information and company performance according to research conducted by Matende and Patrick (2013) that is ERP system is designed to be able to perform information process in determining strategy, management analysis and function in decision making.

Table 2 - t-test

\begin{tabular}{|c|c|c|c|c|c|}
\hline No. & & & Mean & S.D & P-value \\
\hline \multirow{2}{*}{1.} & \multirow{2}{*}{ Predictive Value } & Adopter & 18.56 & 1.07 & \multirow{2}{*}{0.00} \\
\hline & & Non-Adopter & 11.70 & 2.21 & \\
\hline \multirow{2}{*}{2.} & \multirow{2}{*}{ Timeliness } & Adopter & 25.56 & 2.37 & \multirow{2}{*}{0.00} \\
\hline & & Non-Adopter & 18.53 & 4.26 & \\
\hline \multirow{2}{*}{3.} & \multirow{2}{*}{ Feedback Value } & Adopter & 19.70 & 2.23 & \multirow{2}{*}{0.00} \\
\hline & & Non-Adopter & 16.07 & 1.89 & \\
\hline \multirow{2}{*}{4.} & \multirow{2}{*}{ Firm Performance } & Adopter & 40.36 & 3.90 & \multirow{2}{*}{0.00} \\
\hline & & Non-Adopter & 31.67 & 5.25 & \\
\hline
\end{tabular}

Source : Data processed, 2017.

The mean of predictive value indicates that firm adoption is bigger compared to firms that do not adopt ERP and p-value 0,00 this shows that p-value is smaller than probability level 0.05 so in other words $\mathrm{H} 1$ accepted that there is difference between adopted company and companies that are not adopted are associated with predictive value. In this study shows the ERP system capable of presenting past information and presenting future information.

Kanellou and Charalambos (2013) research states that the ERP system affects users of financial statements one of them investors, investors prefer financial statements that can predict future information and can present the information of the past. Galbraith (2002) the use of ERP will effectively have benefits associated with the uncertainty of activity costs, this will affect the quality of information for managers.

In Table II the mean of timeliness indicates greater value than the adoption company that is 25.56 than the non adoption ERP company of 18.53 -value of timeliness also shows the value below the probability level that is 0.00 so that the result of $\mathrm{H} 2$ is accepted. This shows that the implementation of ERP system has significant effect on the timeliness in financial reporting so that the information generated does not expire.

This is in accordance with the research of Trigo et al. (2014) that with the implementation of ERP system able to answer the company's concern in presenting the financial statements on time, so that financial statements can provide fast information, users of financial statements can also access the financial statements udah so easy in making decisions and decisions taken can reflect the circumstances indeed.

The processing of financial statements briefly can reduce the cost as said in the study Elragal and Moutaz (2012) without using ERP system financial report processing will be done repeatedly so it requires a considerable cost while with the ERP system financial statements can be processed with a short time so that the cost issued can be reduced. Stefanou (2002) states that the ERP system is a combination of business applications and procedures into a single database, the system also provides real-time information to the company.

The results shown in table II rmean from the feedback value of companies that adopted the larger ERP system 3.63 ie 19.70 compared with companies that did not adopt the ERP and the table shows the value of $p$-value $0.00<0.05$ so that $\mathrm{H} 3$ accepted ie there is a significant difference between adopted companies and companies that do not adopt ERP. Companies that adopt ERP have the ability to fix errors that occurred in the past.

O'Brien (2015) states that ERP systems can improve the quality of information and can correct errors that occur but this does not happen if the human resources or employees are less reliable in operating or have less knowledge of the ERP system.

The result of the firm performance receiving $\mathrm{H} 4$ indicates that there is a significant difference between companies adopting ERP systems and companies that do not adopt this 
system because the mean of the companies adopted by ERP is much larger than those that do not adopt that is 40.36 and p-value shows the result 0.00 in other words smaller than the probability of 0.05 .

Research conducted in Malaysia and Indonesia by Fernandez, et al. (2017) shows that by applying ERP system then the performance of the company will improve the effectiveness and efficiency of company performance. So this research encourages public sector to apply ERP system to get better result. Research conducted by Cotteleer and Bendoly (2006) states that the ERP system has a significant effect on company performance which includes the availability of information, quality information, inventory management and on time delivery.

\section{CONCLUSION}

This study concludes that there are significant differences between companies that adopt ERP systems and do not adopt ERP systems associated with relevant values consisting of predictive value, timeliness, and feedback value as well as company performance. ERP systems can present the information of the past as well as the future so that the company will have better information from other companies and can make better and more rational company decisions.

ERP system can process financial statements with a short so that companies can take decisions quickly this can minimize costs and can provide the right information, ERP system also affects the value of corporate feedback so that companies can correct mistakes of the past and can make better decisions so it will improve company performance as well. Further research is expected to obtain more data and add some variables that affect the implementation of ERP.

\section{REFERENCES}

1. Albers, J. A. dan Trinidad, A.I. 2006. Knowledge Management Software: A Selection Process. CACC Journal, Reprinted from Asia-Pacific Tech Monitor, pp. 35-41.

2. Alcivar, Isabel dan Andres G. Abad. 2016. Design and evaluation of a gamified system for ERP training. Computers in Human Behavior 58 (2016) 109-118

3. Attayah, F. Osama dan Ibrahim M. Sweiti. 2014. Impact of ERP System Using on the Accounting Information Relevance: Evidence from Saudi Arabia. GSTF Journal on Business Review (GBR) Vol.3 No.2, March 2014

4. Beheshti, H.M dan C.M. Beheshti. 2010. Improving Productivity and Firm Performance with Enterprise Resource Planning. Enterprise Information Systems 4(4), pp 445-472.

5. Chand, D. Hachey, J. hunton, V. Owhoso, S. Vasudevan. 2005. A balanced scorecard based framework for assessing the strategic impacts of ERP systems. Computer Industry 56 (6) $558-572$.

6. Chou, Huey-Wen, et, al. 2014. Knowledge sharing and ERP system usage in postimplementation stage. Computers in Human Behavior 33 (2014) 16-22

7. Cotteler, M. J., dan Bendoly, E. 2006. Order lead-time improvement following enterprise information technology implementation : An empirical study. MIS Quarterly, 30(3). 643660

8. Dechow, N. dan Mouritsen, J. 2005. Enterprise Resource Planning Systems, Management Control and the Quest for Integration. Accounting, Organizations and Society 30(7-8), 691-733

9. Ehie, I. C. dan Madsen, M. 2005. Identifying Critical Issues in Enterprise Resource Planning (ERP). Computers in Industry, vol. 56, pp. 545-557

10. Elragal, Ahmed dan Moutaz Haddara. 2012. The Future of ERP Systems: look backward before moving forward. Procedia Technology 5 ( 2012 ) $21-30$

11. Ferdows, K., dan Meyer, A.D. 1990. Lasting Improvements in Manufacturing Performance : In Search of a new theory. Journal of Operations Management, 9(2), 168183. 
12. Fernandez, Dahlia, et al. 2017. The Impacts of ERP Systems on Public Sector Organizations. Procedia Computer Science 111 (2017) 31-36

13. Galbraith, J.R. 2002. Designing Organizations : An Executive Guide to Strategy, Structure and Process. New York: John Wiley and Sons Inc.

14. Galy, Edith dan Mary Jane Sauceda. 2014. Post-implementation practices of ERP systems and their relationship to financial performance. Information \& Management 51 (2014) 310-319

15. Gattiker, T. dan D. Goodhue. 2005. What Happens After ERP Implementation : Understanding the Impact of Interdependence and Differentiation on Plant-Level Outcomes. MIS Quarterly 29 (3), pp. 559-585

16. Hitt, L.M. dan E. Brynjolfsson. 1996. Productivity, Business Profitability and Consumer Surplus : Three Different Measures of Information Technology Value. MIS Quarterly 20 (2), pp. 121-142.

17. Hunton, James E., Barbara Lippincott dan Jacqueline L. Reck. 2003. Enterprise resource planning systems: comparing firm performance of adopters and nonadopters. International Journal of Accounting Information Systems 4 (2003) 165-184

18. Kanellou, Alexandra dan Charalambos Spathis. 2013. Accounting benefits and satisfaction in an ERP environment. International Journal of Accounting Information Systems 14 (2013) 209-234

19. Kieso, Weygandt dan Warfield. 2011. Intermediate Accounting. Edisi 12 Erlangga

20. Kocaoglu, Batuhan dan A. Zafer Acar. 2015. Developing an ERP Triggered Business Process Improvement Cycle from a Case Company. Social and Behavioral Sciences 181 ( 2015 ) $107-114$

21. Locke, J. dan Lowe, A. 2007. Fabrications in the Life of an ERP Package. Organization, $14,793-814$.

22. Madapusi, A dan D. D'Souza. 2012. The influence of ERP system implementation on the operational performance of an organization. International Journal of Information Management 32 (2012) 24- 34

23. Matende, Samwel dan Patrick Ogao. 2013. Enterprise Resource Planning (ERP) System Implementation: A case for User participation. Procedia Technology 9 ( 2013 ) 518 - 526

24. May, Jeffrey, et al. 2013. Defining value-based objectives for ERP systems planning. Decision Support Systems 55 (2013) 98-109

25. O'Brien, Tony. 2015. Accounting' for data quality in enterprise systems. Procedia Computer Science 64 ( 2015 ) $442-449$

26. Scott, J dan I. Vessey. 2000. Implementing Enterprise Resource Planning Systems : the Role of Learning from Failure. Information Systems Frontiers 2 (2) pp. 213-232

27. Sevenpri, Candra. 2012. ERP Implementation Success and Knowledge Capability. Procedia - Social and Behavioral Sciences 65 ( 2012 ) 141 - 149

28. Shen, Yung-Chi, et al. 2015. A Study of Enterprise Resource Planning (ERP) System Performance Measurement Using the Quantitative Balanced Scorecard Approach. Computers in Industry 75 (2016) 127-139

29. Stefanou, J. C. 2002. Accounting Information Systems (AIS) Development/ Acquisition Approaches by Greek SME. In European Conference on Accounting Information Systems (ECAIS), Copenhagen, Denmark.

30. Trigo, António, et, al. 2014. Accounting Information Systems: The Challenge of the RealTime Reporting. Procedia Technology 16 ( 2014 ) 118 - 127. 